\title{
IRRESPONSABILIDADE FISCAL AINDA PERSISTE, 15 ANOS APÓS A PUBLICAÇÃo DA LEI
}

Coluna publicada em 7.4.2015: <http://www.conjur.com.br/2015-abr-07/ contas-vista-irresponsabilidade-fiscal-persiste-15-anos-publicacao-lei>

No próximo dia 4 de maio, completam-se 15 anos da publicação da Lei Complementar 101, conhecida como "Lei de Responsabilidade Fiscal".

A Lei de Responsabilidade Fiscal (LRF) foi um marco para o Direito Financeiro, pois veio regular o artigo 163 da Constituição, que prevê lei complementar para estabelecer normas gerais de finanças públicas. Um verdadeiro "divisor de águas" para o período que a antecedeu, marcado por forte inflação e descontrole de contas públicas, e o que se sucedeu após a implementação da lei, em que esses problemas foram bastante reduzidos. Com a estabilização da moeda em 1994, era o documento que faltava para estabelecer normas mais rígidas que permitissem organizar e dar credibilidade às finanças do setor público.

É oportuno aproveitar a data para refletir sobre os avanços dessa lei e as necessidades de aperfeiçoamento.

E o momento atual evidencia a importância do cumprimento dessa lei, como se vê do debate, nestas últimas semanas, acerca da necessidade de "ajuste fiscal" e reequilíbrio nas contas públicas, que, ao que tudo indica, foram muito maltratadas nos últimos anos.

A Lei de Responsabilidade Fiscal assenta-se nos pilares do planejamento governamental, transparência das contas públicas e equilíbrio fiscal, mediante controle das despesas e do endividamento e melhoria da gestão pública. ${ }^{1}$

1 Art. $1^{\circ}, \$ 1^{\circ}$ : A responsabilidade na gestão fiscal pressupõe a ação planejada e transparente, em que se previnem riscos e corrigem desvios capazes de afetar o equilíbrio das contas públicas, mediante o cumprimento de metas de resultados entre receitas e despesas e a obediência a li- 
No que tange ao planejamento governamental, os principais avanços deram-se no âmbito do médio e curto prazo, com a ampliação das funções das leis de diretrizes orçamentárias, que passaram a regular o equilíbrio fiscal, o contingenciamento, controle de custos, avaliação de resultados dos programas de governo e as metas relacionadas ao endividamento público, dentre outras atribuições (LRF, art. $\left.4^{\circ}\right)$.

Funções que não se podem considerar integralmente cumpridas, especialmente no âmbito de estados e municípios, que, no mais das vezes, as ignoram e são omissos em relação a várias dessas atribuições.

O planejamento governamental, especialmente no âmbito federal, tem sido descuidado ultimamente. $\mathrm{O}$ artigo 174 da Constituição praticamente nunca foi aplicado, e não temos planejamento nacional, registrando-se tão somente planos setoriais, como o Plano Nacional de Educação (PNE) aprovado ano passado, para os próximos dez anos, e cujo efetivo cumprimento precisa ser acompanhado, além de ser necessária a aprovação dos planos estaduais e municipais, o que deverá ocorrer até o próximo dia 25 de junho (PNE, art. $8^{\circ}$ ). O planejamento orçamentário de médio prazo, representado pelo PPA, é hoje praticamente uma formalidade, pouca atenção se lhe dá, concentrando o governo suas atenções no Plano de Aceleração do Crescimento (PAC), um planejamento bastante deficiente e que, segundo se noticia, está sendo abandonado. ${ }^{2}$

Houve avanços no que se refere à transparência, prevista nos artigos 48 e 49 da LRF, cuja redação foi aperfeiçoada pela Lei Complementar 131, de 2009, determinando a ampla divulgação das atividades financeiras governamentais e o incentivo à participação popular e realização de audiências públicas. A Lei de Acesso à Informação (Lei 12.527, de 18 de novembro de 2011) ampliou o acesso público às informaçôes governamentais, aumentando a transparência.

Prejuízos à transparência ficaram por conta da "contabilidade criativa", que contaminou as contas públicas nos últimos anos, ${ }^{3}$ distorcendo as informações leva-

mites e condições no que tange a renúncia de receita, geração de despesas com pessoal, da seguridade social e outras, dívidas consolidada e mobiliária, operaçōes de crédito, inclusive por antecipação de receita, concessão de garantia e inscrição em Restos a Pagar.

2 O PAC se esfarela. O Estado de S.Paulo, 27 de fevereiro de 2015; Gustavo Patu, O PAC acabou. Folha de S.Paulo, 2 de março de 2015; Aperto fiscal reduz gasto do PAC em 31,8\%. O Estado de S.Paulo, 30 de março de 2015.

3 Carnaval financeiro: contas "maquiadas" não vão tornar nosso país mais bonito, nesta edição, p. 387-390, e O Direito Financeiro precisa ser levado a sério, e 2015 começou mal, nesta edição, p. $183-188$. 
das ao conhecimento público. Manobras como as "pedaladas fiscais” "só promoveram a quebra de confiança no governo para postergar por pouco tempo as más notícias sobre as finanças públicas, que agora vêm à tona.

Uma clara demonstração que a Lei de Responsabilidade Fiscal existe para ser cumprida, pois atos de gestão fiscal irresponsável como esse só mostram que as consequências aparecem rapidamente, e as tentativas de burlar a lei só resultam em prejuízos à segurança jurídica e à credibilidade no governo.

Entre os pilares em que se sustenta, o equilíbrio fiscal preconizado pela Lei de Responsabilidade Fiscal é o ponto mais sujeito a controvérsias.

De início, já releva destacar que, na questão do endividamento público, apesar de a lei fazer referência a toda a Federação, até o momento só foram implantadas as restriçóes para os entes subnacionais - estados, Distrito Federal e municípios (vide Resoluções 40 e 43 do Senado Federal, ambas de 2001), permanecendo a União sem limites para sua dívida. Uma omissão que se espera seja sanada o mais brevemente possível pelo Senado Federal.

Muitas das recentes discussóes sobre o ajuste fiscal decorrem da implementação da Lei Complementar 148, de 25 de novembro de 2014, que autorizou a União a recalcular as dívidas dos entes subnacionais, que agora lutam pela sua efetiva implementação.

A rigidez nas regras limitadoras das despesas públicas e do endividamento, se considerada a anualidade de nosso orçamento, restringe a possibilidade de implementação de políticas anticíclicas de caráter plurianual, dificultando, muitas vezes, o atendimento de necessidades públicas fundamentais. Trata-se de um dos aspectos que mais merecem atenção e reflexão, a fim de que se possam estabelecer mecanismos que permitam ampliar a flexibilização, possibilitando, se conveniente ao interesse público, aceitar eventuais déficits temporários que possam ser úteis para fomentar o desenvolvimento econômico e social, sem prejuízo de um equilíbrio fiscal em prazo mais longo que o anual.

Oportuno lembrar que a principal regra limitadora das despesas públicas, o artigo 20 da LRF, que impóe tetos para os gastos com pessoal, especificando porcentuais para cada um dos Poderes em cada unidade da Federação, está sendo questionado por várias ações declaratórias de inconstitucionalidade, que ainda não tiveram seu mérito apreciado em caráter definitivo. A segurança jurídica exige que essas ações sejam julgadas o quanto antes, não se justificando permanecerem pen-

4 Atenção, caro leitor, pedalar faz mal à saúde!, nesta edição, p. 391-394. 
dentes de julgamento há mais de uma década. Hoje reunidas para julgamento com a ADI 2.238, várias delas (ADI 2.256, ADI 2.241, ADI 2.261 e ADI 2.365) discutem a constitucionalidade de outros dispositivos importantes da LRF, como os artigos $9^{\circ}, 11,12,15,35,56$, além de outros.

Ainda no tocante ao controle das despesas públicas, cabe destaque à regulamentação das renúncias de receitas - os "gastos tributários" - previstas no artigo 14 da LRF, onde se estabelecem exigências para a concessão de benefícios fiscais. Exigências estas que, se tivessem sido cumpridas à risca, não teriam permitido os excessos nas desonerações tributárias estão ocupando o noticiário recente e tornando necessária boa parte do ajuste fiscal. Mais uma demonstração de irresponsabilidade fiscal e necessidade de respeito a essa lei, cujos descumprimentos só causam prejuízos ao desenvolvimento do País.

No âmbito da gestão pública, vê-se a necessidade de efetiva implantação da lei na sua integralidade, o que ainda não ocorreu, apesar de transcorridos quinze anos. É o caso, por exemplo, da criação do Conselho de Gestão Fiscal, órgão paritário previsto no artigo 67, a ser composto por representantes de todos os Poderes e esferas de Governo, responsável pela difícil tarefa de harmonizar e coordenar os entes da Federação, bem como fomentar as práticas de gestão fiscal responsável e aumento da eficiência na administração pública, além de adotar normas de padronização e consolidação das contas públicas. Normas estas que, na falta deste órgão, vem sendo estabelecidas provisoriamente pela Secretaria do Tesouro Nacional, nos termos do artigo $50, \$ 2^{\circ}$ da LRF, dando ao Poder Executivo Federal uma supremacia que não se coaduna com os princípios constitucionais da separação de Poderes e do federalismo.

São muitas as questões, e este espaço não comporta discuti-las todas. Vários dos temas ora levantados voltarão a ser especificamente abordados em outras oportunidades. Mas é importante aproveitar a data para chamar a atenção e fomentar o debate.

A Lei de Responsabilidade Fiscal, como toda lei, com o decorrer do tempo e as naturais modificaçôes pelas quais passa a sociedade, exige aperfeiçoamentos. Debates e propostas são sempre bem-vindos. Tentativas de burlá-la, contorná-la ou violá-la não são bem-vindas, pois o ordenamento jurídico está aí para ser cumprido, e a atual situação financeira pela qual passa o País só mostra que desrespeitá-lo não vale a pena. A conta não demora a chegar para ser paga. 